\title{
Ультразвукова архітектоніка щитоподібної залози після використання при хірургічному лікуванні зварювальних технологій
}

\begin{abstract}
Мета роботи: вивчення стану залишеної тканини щитоподібної залози та особливостей судинної перфузії за ультразвуковою та доплерівською характеристикою, після операції з перебігом часу, при використанні під час хірургічного втручання зварювального високочастотного коагулятора.

Матеріали і методи. Операційні втручання з використанням високочастотного коагулятора ЕХВА - 350МС та ЕКВЗ-300 з частотою 66 кГц і 440 кГц у моно- та біполярному режимах виконували у хворих, які перебували на стаціонарному лікуванні в Київському міському центрі ендокринної хірургії, який є структурним підрозділом Київської міської клінічної лікарні № 3. У 230 хворих вивчили можливості застосування електрокоагуляції або різання тканин щитоподібної залози за останні 5 років, у всіх варіантах операційного втручання за об’ємом: резекція однієї, обох часток щитоподібної залози - у 13 (6 \%), гемітиреоїдектомії - у 60 (26 \%), гемітиреоїдектомії з резекцією іншої частки - у 23 (10 \%), тиреоїдектомії - у 125 (54 \%), тиреоїдектомії з шийною дирекцією - у $9(4$ \%) хворих.

96 хворим після операції на щитоподібній залозі із збереженням тканини виконано ультразвукову доплерографію на 10 день, через 1, 6, 12 місяців. Спроможності апаратів давали змогу отримувати зображення залишеної тканини, визначити її величину, ехоструктуру, розміри знову виявлених у тиреоїдному залишку включень.

Результати досліджень та їх обговорення. На 10 день післяопераційні обстеження у всіх хворих показували неоднорідні гіпоанехогенні ділянки без чітких меж та сталих ехоструктурних значень.

У 15 (15 \% ) хворих через 10 днів після операції в тиреоїдному залишку візуалізувалися дрібні гематоми (4-8 мм) у вигляді гідрофільних ділянок із чіткими контурами без капсули, у 18 (19 \%) - локальні або зливні крововиливи низької щільності з чіткими нерівними контурами. 3 перебігом часу гематоми та крововиливи розсмоктувалися, тому на 6 місяць після операції та пізніше відсутня їх візуалізація, проте спостерігається організація та фіброз.

У 11 (12 \% ) пацієнтів на 6 місяці спостережень після операції у місцях прицільної електрокоагуляції формуються 2-3 мм гіперехогенні, неоднорідної структури включення, без чітких меж, з нерівними і нечіткими контурами. Кількість та розмір гранульом залежить від гістологічної структури оперованої тканини, які при лімфоїдній інфільтрації автоімунного генезу можуть заповнювати весь тиреоїдний залишок. Додатково на цьому фоні, першого року досліджень, у 18 (19 \%) пацієнтів можна визначити дрібні гіперехогенні утворення, що дають звукову доріжку (кальцинати). Через 2-3 роки після операції встановлено збереження гранульом меншого розміру лише у 4 хворих. Через 5-6 місяця після операції у 17 (18 \% ) хворих у паренхімі ізольовано або навколо гіперехогенних включень встановлені невеликі первинні кісти - гідрофільні ділянки з чіткими контурами. Лише у 21 (22 \% ) обстеженнях вже з перших днів, при виконанні економної резекції та операцій в зоні перешийку і медіального краю обох часток, трапляється здорова (не змінена) паренхіма при відсутності лімфоїдної інфільтрації автоімунного генезу. У 52 (54 \% ) пацієнтів на 6 місяць після операції структура паренхіми однорідна, дрібнозерниста без патологічних змін.
\end{abstract}

Ключові слова: хірургічне лікування щитоподібної залози; високочастотна електрокоагуляція; тиреоїдний залишок.

Постановка проблеми і аналіз останніх досліджень та публікацій. Захворювання щитоподібної залози, що підлягали операційному лікуванню, відіграє провідну роль в ендокринній хірургії, виходять на перше місце серед різноманітних ендокринопатій та набувають особливого значення у подальшій діагностиці та продовженні лікування в післяопераційному періоді. Особливість специфіки діагностики викликає зростаючий інтерес, особливо до її несприятливих форм - раку щитоподібної залози [9. Із зростанням патології щитоподібної залози (в тому числі раку) збільшилась кількість хворих, яким виконували операційне лікування. При спостереженні за такими хворими в ранньому та пізньому післяопераційному періоді, не зважаючи на відомі діагностичні тести, виникають певні проблеми, що зобов’язало нас вивчити стан залишеної тканини (культей) щитоподібної залози з врахуванням використання нових методик під час операції та діагностичних обстежень.

При операціях на щитоподібній залозі можуть виникати труднощі та типові ускладнення: операційні та післяопераційні кровотечі, пошкодження нервів, що забезпечують голосову функцію, а також видалення або порушення кровопостачання, прилеглих до оперованого органа, паращитоподібних залоз. Вказані труднощі прямо залежать від хірургічної тактики, якості використовуваного інструментарію та методик гемостазу $[5,6,8]$.

Тому питання використання більш ефективного своєчасного гемостазу під час операційного втручання, скорочення часу виконання операції, що дало б змогу ефективно виконати запланований об’єм та максимально уникнути ускладнень традиційною оперативною технікою 3 використанням затискачів на тканину чи судини 3 
перев'язкою судин лігатурою або методом прошивання із зав'язуванням лігатури прилеглих м'яких тканин щитоподібної залози, не вирішується. Xiрургічні підходи при лікуванні хворих із різноманітною патологією щитоподібної залози на сьогодні внаслідок зростання хірургічної активності при онкологічній настороженості вимагають пошуку альтернативних менш травматичних методів гемостазу з використанням сучасного, особливо вітчизняного, оснащення та технологій $[3,4]$.

Розроблену та апробовану технологію електрозварювання біологічних тканин колективом дослідників Інституту електрозварювання ім. Є. О. Патона НАН України успішно впроваджено в ендокринну хірургію. Надійне перекриття кровоносних судин при електрозварюванні - альтернатива нитковим лігатурам $[4,5,6]$.

Використання у післяопераційному періоді залишеної тканини щитоподібної залози ультразвуковим дослідженням в В-режимі сьогодні поєднується з кольоровою доплерографією та з режимом енергетичного доплера. Питання визначення стану залишеної тканини, її кровообіг та зміни кровопостачання по периферії з перебігом часу дуже складні і вимагають подальшої наукової розробки [9].

Складним завданням $є$ диференціація залишеної деформованої операцією тканини та поява або залишення в тканині залози осередків у вигляді вузлів, вогнищ хронічного тиреоїдиту та активних чи пасивних зон кровообігу. Зрушення цих труднощів у позитивний бік ми пов'язуємо з використанням кольорового доплерівського картування [1, 7, 9].

Мета роботи: вивчення стану залишеної тканини щитоподібної залози та особливостей судинної перфузії за ультразвуковою та доплерівською характеристикою, після операції з перебігом часу, при використанні під час хірургічного втручання зварювального високочастотного коагулятора.

Матеріали і методи. Операційні втручання 3 використанням високочастотного коагулятора EXBA - 350MC та EKB3-300 з частотою 66 кГц i 440 кГц в моно- та біполярному режимах виконували у хворих, що перебували на стаціонарному лікуванні в Київському міському центрі ендокринної хірургії, який є структурним підрозділом Київської міської клінічної лікарні № 3.

У 230 хворих вивчили можливості застосування електрокоагуляції або різання ткани щитоподібної залози за останні 5 років, у всіх варіантах операційного втручання за об'ємом: резекція однієї, обох часток щитоподібної залози - у 13 (6 \%), гемітиреоїдектомії - у 60 (26 \%), гемітиреоїдектомії з резекцією іншої частки - у 23 (10 \%), тиреоїдектомії - у 125 (54 \%), тиреоїдектомії 3 шийною ди- рекцією - у 9 (4 \%) хворих. Якість гемостазу та надійність сполучення тканин оцінювали після стиснення тканини інструментами при оптимальній потужності (частоті від 66 до 440 кГц) та відповідній експозиції часу - залежно від інструмента, типу та товщини захоплення м'яких тканин. На всіх етапах хірургічного втручання використовували різні типи інструментів: монополярний ніж для розсічення м'яких тканин, коагуляційний пінцет, плоский коагуляційний затискач, зубчастий коагуляційний затискач. Всі маніпуляційні дії з інструментами та апаратурою здійснювали при помірному стисненні інструмента, оптимальній потужності (при частоті від 66 до 440 кГц) та відповідній експозиції часу - залежно від інструмента, типу та товщини захоплення м'яких тканин. Загальна суть ïx полягає у тому, що замикання електричного кола між браншами пінцета чи затискача разом з захопленими м'якими тканинами створює умови для коагуляції чи різання. Стан гемостазу оцінювали шляхом спостереження та вимірювання втраченої крові під час та після операції із зіставлення динамічних змін “червоної крові”.

У 96 хворих після операції на щитоподібній залозі із збереженням тканини виконано ультразвукову доплерографію на 10 день, через 1, 6, 12 місяців. Дослідження проводили з використанням апарата Aloka 1700, HDI 5000 та HDI 3000 (ATL CШA) 3 лінійним датчиком L12-5Мгц. Спроможності апаратів давали змогу отримувати зображення залишеної тканини, визначити її величину, ехоструктуру, динамічні зміни параметрів, розміри знову виявлених у тиреоїдному залишку включень.

\section{Результати досліджень та їх обговорення.} На 10 день післяопераційні обстеження у всіх хворих показували неоднорідні гіпоанехогенні ділянки без чітких меж та сталих ехоструктурних значень (крововили, невеликі гематоми, імбібіція кров'яним компонентом тканин, прилеглих до тиреоїдного залишку, початок зони фіброзу й осифікації у тканині, число, розмір і характер яких залежав від кількості залишеної тканини, наявності післяопераційних змін у паренхімі, часу, що пройшов від початку операції (табл.).

Деякі післяопераційні включення в ділянках тиреоїдного залишку можуть спостерігатися не у єдиному варіанті, а поєнуватися у групи з іншими.

Враховуючи використання електрокоагуляції на тканині та судинах без накладання лігатур, бранші інструмента в біполярному режимі апаратів ЕXВА - 350MC- в режимі Бі2 з потужністю 180-200 Вт на 10-12 секунд захоплювали структуру завтовшки 4-5 мм створювала однорідну суцільну зону сірувато-коричневого забарвлення, 


\section{З ДОСВІДУ РОБОТИ}

Таблиця. Післяопераційні включення в різні періоди спостережень

\begin{tabular}{||l|c|c|c|c||}
\hline $\begin{array}{c}\text { Післяопераційні } \\
\text { включення }\end{array}$ & $\begin{array}{c}\text { Через } 10 \text { днів } \\
\text { після операції }\end{array}$ & $\begin{array}{c}\text { Через } 1 \text { місяць } \\
\text { після операції }\end{array}$ & $\begin{array}{c}\text { Через 6 місяців } \\
\text { після операції }\end{array}$ & $\begin{array}{c}\text { Через } 1 \text { рік після } \\
\text { операції }\end{array}$ \\
\hline Гематоми & $15(15 \%)$ & $3(3 \%)$ & - & - \\
\hline Крововиливи & $18(19 \%)$ & $14(15 \%)$ & - & - \\
\hline Імбібіція прилеглих тканин & $39(41 \%)$ & $24(25 \%)$ & $10(10 \%)$ & - \\
\hline Кістозні включення & - & - & $7(8 \%)$ & $10(10 \%)$ \\
\hline Фіброзні ділянки і осифікати & $3(3 \%)$ & $6(6 \%)$ & $10(10 \%)$ & $18(19 \%)$ \\
\hline Гранульоми & - & $6(6 \%)$ & $11(12 \%)$ & $16(17 \%)$ \\
\hline Здорова (не змінена) тканина & $21(22 \%)$ & $43(45 \%)$ & $58(60 \%)$ & $52(54 \%)$ \\
\hline
\end{tabular}

що характерно для процесів термічної денатурації білка, при цьому зона впливу між електродами прямо залежить від потужності та експозиції. Контрольований, рівномірний вплив електрокоагуляції на тканину щитоподібної залози дає можливість використати методику для гемостазу та роботи на складних ділянках по периферії капсули залози, в зоні паращитоподібних залоз та гортанних нервів. Одночасне зварювання-розсічення капсули залози виконували ріжучим пінцетом із тонкими загостреними робочими поверхнями.

У всіх 96 хворих електрокоагуляцію виконували з метою попередження кровотечі - “в сухому полі” з використанням пінцета без накладання затискачів та перев'язування нитковими лігатурами, це допомагало працювати більш прицільно й прискорювало наступні етапи втручання. У 4 (4 \%) хворих кровотечу зупиняли шляхом захоплення судини пінцетом з подальшою коагуляцією. Спосіб резекції тканини щитоподібної залози з формуванням кукси або пересічення перешийку здійснювався шляхом захоплення зубчастим затискачем і вмикання струму. Завдяки комплексу технічних маніпуляцій тривалість операції скорочувалася на 40-50 хвилин, тому ехографічна картина післяопераційних включень в різний період спостережень буде суттєво відрізнятися від попередніх досліджень.

У 15 (15 \% ) хворих через 10 днів після операції в тиреоїдному залишку візуалізувалися дрібні гематоми (4-8 мм ) у вигляді гідрофільних ділянок із чіткими контурами без капсули, у 18 (19 \% ) - спостерігалися локальні або зливні крововиливи низької щільності з чіткими нерівними контурами. 3 перебігом часу гематоми та крововиливи підлягають розсмоктуванню, тому на 6 місяць після операції та пізніше відсутня їх візуалізація, проте спостерігається організація та фіброз, тобто залишена паренхіма стає неоднорідною, гіперехогенною, місцями чергуються фіброзні ділянки з сполучнотканинними прошарками, що надає залишку часточкову структуру. На цьому етапі обстеження слід чітко відмежувати появу нових вузлів - рецидиву від явищ організації гематоми чи крововиливу, автономної (незалежно від виконання операції) автоімунної дифузної чи вогнищевої лімфоїдної інфільтрації і фіброзу залишеної тканини щитоподібної залози.

У 11 (12 \% ) дослідженнях на 6 місяць спостережень після операції у місцях прицільної електрокоагуляції формуються 2-3 мм гіперехогенні, неоднорідної структури включення, без чітких меж, 3 нерівними і нечіткими контурами. Кількість та розмір гранульом залежить від гістологічної структури оперованої тканини, які при лімфоїдній інфільтрації автоімунного генезу можуть заповнювати весь тиреоїдний залишок. Додатково на цьому фоні, першого року досліджень, у 18 (19 \%) пацієнтів можна визначити дрібні гіперехогенні утворення, що дають звукову доріжку (кальцинати). Через 2-3 роки після операції видно збереження гранульом меншого розміру лише у 4 хворих. Через 5-6 місяця після операції у 17 (18 \% ) хворих у паренхімі ізольовано або навколо гіперехогенних включень виявлено невеликі первинні кісти - гідрофільні ділянки з чіткими контурами. Лише у 21 (22 \%) обстежені вже з перших днів при виконанні економної резекції та операцій в зоні перешийку і медіального краю обох часток, тримається здорова (не змінена) паренхіма при відсутності лімфоїдної інфільтрації автоімунного генезу. У 52 (54 \%) пацієнтів на 6 місяць після операції структура паренхіми однорідна, дрібнозерниста без патологічних змін.

Виконання операції з приводу багатовузлового зоба та поєднання вузлів із лімфоїдною інфільтрацією і фіброзом при максимальному видаленні залози і формуванні культі з фрагментів здорової тканини структура тиреоїдного залишку набуває неоднорідності. При аналізі характеристики залишеної тиреоїдної тканини після операції за ультразвуковими та доплерівськими значеннями необхідно вказати, якщо на 1 - 2 тижні внаслідок набряку, гематоми, крововиливу ехострукту- 


\section{З ДОСВІДУ РОБОТИ}

ра різноманітна, тиреоїдний залишок із нечіткими та нерівними контурами, то в кінці 1 року він набуває чітких та рівних меж.

Висновки. Використання технологій високочастотної електрокоагуляції та зварювання м'яких тканин забезпечує надійний гемостаз, скорочує основний етап операції, дає можливість уникати ускладнень, лігатурних гранулем та, у загальному, покращує результати хірургічного лікування патології щитоподібної залози.

Ультразвукове дослідження з доплерографією залишеної тканини після операції на щитоподіб-

\section{СПИСОК ЛІТЕРАТУРИ}

1. Ультразвуковая картина послеоперационных изменений в тиреоидном остатке / В. Г. Абалмасов, О. Г. Шайдулин, Т. Д. Евменова, И. Х. Шайдулин // Эхография. 2001. - Т. 2, № 3. - С. 246-250.

2. Кваченюк А. М. Характеристика репаративного процесу після хірургічних втручань на щитоподібній залозі з використанням електрозварювання біологічних тканин / А. М. Кваченюк, Л. Л. Сук // Ендокринологія. - 2016. - № 4. - С. 315-320. 3. Маринский Г. С. Новое оборудование для высокочастотной сварки живых мягких тканей / Г. С. Маринский, В. А. Ткаченко, А. В. Чернець // Клін. хірургія. - 2010. - № 11. - С. 72.

4. Ничитайло М. Ю. Досвід застосування високочастотного електрозварювання в ендокринній хірургії / М. Ю. Ничитайло, О. М. Литвиненко, О. М. Гулько // Клінічної хірургія. - 2013. - № 8. - C. 5-8.

5. Пат. 65220 Україна, МПК (2011) А61В 17/00. Спосіб гемостазу при проведенні хірургічного втручання на щитоподібній залозі / Шляхтич С. Л., Комісаренко І. В., Сук Л. Л.,

\section{REFERENCES}

1. Abalmasov, V.G., Shaydulin, O.G., Evmenova, T.D., \& Shaydulin, I.Kh. (2001). Ultrazvukovaya kartina posleoperatsyonnykh izmeneniy $\mathrm{v}$ tiroidnom ostatke [Ultrasound picture of postoperative changes in the thyroid remnant]. Ekhografiya Echography, 2 (3), 246-250 [in Russian].

2. Kvachenyuk, A.M., \& Suk, L.L. (2016). Kharakterystyka reparatyvnoho protsesu pislia khirurhichnykh vtruchan na shchytopodibnii zalozi z vykorystanniam elektrozvariuvannia biolohichnykh tkanyn [Characteristics of the reparative process after surgical interventions on the thyroid gland using electric welding of biological tissues]. Endokrynolohiia - Endocrinology, 4, 315-320 [in Ukrainian].

3. Marinskiy, G.S., Tkachenko, V.A., \& Chernets, A.V. (2010). Novoe oburudovaniye dlya vysokochastotnoy svarki zhyvykh myagkikh tkaney [New equipment for high-frequency welding of live soft tissue]. Klinichna khirurhiia - Clinical Surgery, 11, 72 [in Russian].

4. Nychytailo, M.Yu., Lytvynenko, O.M., \& Hulko, O.M. (2013). Dosvid zastosuvannia vysokochastotnoho elektrozvariuvannia $\mathrm{v}$ endokrynnii khirurhii [The experience of using high-frequency electric welding in endocrine surgery]. Klinichna khirurhiia Clinical Surgery, 8, 5-8 [in Ukrainian]. ній залозі з приводу ії патологічних станів дає нам чітку картину про суттєві зміни, що відбуваються у паренхімі при використанні високочастотної електрокоагуляції. Нормалізація ехоструктури тиреоїдного залишку відбувається протягом одного року спостереження і вже через рік є найбільш сталою 3 урахуванням функціональної гіперплазії. Чітке уявлення про перебіг змін у тиреоїдному залишку дає можливість встановити післяопераційний діагноз, уникнути діагностичних помилок - гіпердіагностики рецидивів вузлового зоба, автоімунного тиреоїдиту (вогнищевої форми), явищ неоплазії, виконати своєчасну корекцію лікування.

Булдигіна Ю. В. ; заявник і патентовласник ДУ “Інститут ендокринології та обміну речовин ім. В. П. Комісаренка НАМН України” (UA). - № u201106582 ; заявл. 26.05.11 ; опубл. 25.11.11, Бюл. № 22.

6. Швед О. Є. Обгрунтування нового хірургічного методу гемостазу : дис. ... канд. мед. наук / О. Є. Швед. - Київ, 2008. $-171 \mathrm{c}$

7. Solbiati L., Cherbaneay J.,W. The thyreoid gland // Ed. C.M. Rumack, S.R. Wilson / Diagnostic Ultrasound.- 4 th ed.Philadelphia : Elsevier Wosby, 2011.- P. 708 - 749.

8. Manouras A. Novel hemostatic devices in thyroid surgery: electrothermal bipolar vessel sealing system and harmonic scalpel / A. Manouras, H. E. Markogiannakis, P. B. Kekis [et al.] // Expert. Rev. Med. Devices. - 2008. - Vol. 5, N 4. - P. 447 - 466. 9. American Association of Clinical Endocrinologists Medical Guidelines for Clinical Practice for the Diagnosis and Management of Thyroid Nodules: AACE/AME Task Force on Thyroid Nodules // Endocr. Pract. - 2006. - Vol. 12. - P. 63-102.

5. Shliakhtych, S.L., Komisarenko, I.V., \& Suk, L.L., \& Buldyhina, Yu.V. (2011). Petent Ukraine No. 65220 MPK A61B 17/00. Sposib hemostazu pry provedenni khirurhichnoho vtruchannia na shchytopodibnii zalozi [Method of hemostasis during surgical intervention on thyroid gland]. Applicant and patent holder Institute of Endocrinology and Metabolism by V.P. Komisarenko of the NAMS of Ukraine (UA). No. u201106582; stated 26.05.11; published 25.11.11, Bul. No. 22 [in Ukrainian]. 6. Shved, O.Ye. (2008). Obhruntuvannia novoho khirurhichnoho metodu hemostazu [Substantiation of new surgical method of hemostasis]. Candidate's thesis. Kyiv [in Ukrainian].

7. Solbiati, L., \& Cherbaneay, J.W. (2011). The thyroid gland. Diagnostic Ultrasound. 4th ed. Rumack, C.M., \& Wilson, S.R. (Ed.). Philadelphia: Elsevier Wosby.

8. Manouras, A., Markogiannakis, H.E., \& Kekis, P.B. (2008). Novel hemostatic devices in thyroid surgery: electrothermal bipolar vessel sealing system and harmonic scalpel. Expert. Rev. Med. Devices. 5 (4), 447-466.

9. (2006). American Association of Clinical Endocrinologists Medical Guidelines for Clinical Practice for the Diagnosis and Management of Thyroid Nodules : AACE/AME Task Force on Thyroid Nodules. Endocr. Pract., 12, 63-102.

Отримано 19.03.2019 


\section{ULTRASONIC ARCHITECTONICS OF THYROID GLAND AFTER USE OF SURGICAL TREATMENT OF WELDING TECHNOLOGIES}

The aim of the work: to study the state of residual tissue of the thyroid gland and the features of vascular perfusion by ultrasound and Doppler characteristics, after surgery with time, when used during surgical intervention of a welding high-frequency coagulator. Materials and Methods. Operative intervention using the high-frequency coagulator EKhVA-350MS and EKVZ-300 with frequency of $66 \mathrm{kHz}$ and $440 \mathrm{kHz}$ in mono- and bipolar regimens was performed in patients undergoing in-patient treatment at the Kyiv City Center for Endocrine Surgery, which is a structural subdivision of the Kyiv City Clinical Hospital No. 3 . In 230 patients studied the possibility of using electrocoagulation or cutting of thyroid tissues during the last 5 years, in all variants of surgical intervention in volume: resection of one, both parts of the thyroid - in 13 (6\%), hemithyroidectomy - in $60 \%$ (26\%) with resection of another part - in 23 (10\%), thyroidectomy - in 125 (54\%), cervical thyroidectomy - in 9 (4 \%) of patients.

96 patients after operation on a thyroid gland with tissue preservation underwent ultrasound doplerography on day 10 , after 1 , 6 , 12 months. The capabilities of the apparatus allowed to get the image of the left fabric, determine its size, echo structure, the sizes of newly discovered in the thyroid residue inclusions.

Results and Discussion. At day 10 postoperative examinations in all patients showed heterogeneous hypoanechogenic areas without clear boundaries and stable echostructural values. In 15 (15\%) patients, 10 days after surgery, small hematomas (4-8 mm) were visualized in the thyroid residue in the form of hydrophilic areas with clear contours without capsule, in 18 (19 \%) - local or drainage hemorrhages of low density with clear irregularities contours with the passing of time, hematomas and hemorrhages resolved, therefore, 6 months after the operation and later there is no visualization of them, but an organization and fibrosis are observed.

In 11 (12\%) patients for 6 months of post-surgery observation, 2-3 mm hyperherogenic, heterogeneous inclusion structures, without clear boundaries, with uneven and unclear contours, are formed in 2-3 mm of electrocoagulation. The amount and size of the granule depends on the histological structure of the operative tissue, which, when lymphoid infiltration of the autoimmune genesis, can fill the entire thyroid residue. Additionally, in this background, in the first year of research, in 18 (19 \%) patients, small hyperhognogenic nodes that give an audio track (calcine) can be identified. 2-3 years after the operation the preservation of a smaller size granule was established only in 4 patients. In 5-6 months after the operation, 17 (18\%) patients with parenchyma isolated or around hyperherogenic inclusions established small primary cysts - hydrophilic areas with clear contours. Only in 21 (22 \%) surveys from the first days, when performing economical resection and operations in the area of the isthmus and the medial edge of both parts, a healthy (unchanged) parenchyma occurs in the absence of lymphoid infiltration of autoimmune genesis. In 52 (54 \%) patients for 6 months after surgery, the structure of parenchyma is homogeneous, fine-grit without pathological changes.

Key words: surgical treatment of thyroid gland; high-frequency electrocoagulation; thyroid remnant.

Н. М. СТЕЦЬ, В. Р. АНТОНИВ, Т. Н. ГАЛИГА

Национальный медицинский университет имени А. А. Богомольца, Киев

\section{УЛЬТРАЗВУКОВАЯ АРХИТЕКТОНИКА ЩИТОВИДНОЙ ЖЕЛЕЗЫ ПОС.ЛЕ ИСПОЛЬЗОВАНИЯ ПРИ ХИРУРГИЧЕСКОМ ЛЕЧЕНИИ СВАРОЧНЫХ ТЕХНОЛОГИЙ}

Цель работы: изучение состояния оставленной ткани щитовидной железы и особенностей сосудистой перфузии по ультразвуковой и допплеровской характеристике, после операции с ходом времени, при использовании во время хирургического вмешательства сварочного высокочастотного коагулятора.

Материалы и методы. Оперативные вмешательства с использованием високочастотного коагулятора ЭХВА - 350МС и ЭКВЗ 300 с частотой 66 кГц и 440 кГц в моно- и биполярном режимах выполняли у больных, находящихся на стационарном лечении в Киевском городском центре эндокринной хирургии, который является структурным подразделением Киевской городской клинической больницы № 3. В 230 больных изучили возможности применения электрокоагуляции или резекции тканей щитовидной железы за последние 5 лет, во всех вариантах операционного вмешательства по объему: резекция одной, обеих долей щитовидной железы - у 13 (6 \%), гемитиреоидэктомии - 60 (26 \%), гемитиреоидэктомии с резекцией другой доли - у 23 (10 \%), тиреоидэктомии - в 125 (54 \%), тиреоидэктомии с шейной дисекцией - у 9 (4 \%) больных.

96 больным после операции на щитовидной железе с сохранением ткани выполнено ультразвуковую допплерографию на 10 день, через 1, 6, 12 месяцев. Способности аппаратов позволяли получать изображение оставленной ткани, определить ее величину, эхоструктуру, размеры вновь выявленных в тиреоидном остатке включений.

Результаты исследований их обсуждение. На 10 день послеоперационные обследования у всех больных показывали неоднородные гипоанехогенные участки без четких границ и постоянных эхоструктурних значений.

В 15 (15 \%) больных через 10 дней после операции в тиреоидном остатке визуализировались мелкие гематомы (4-8 мм) в виде гидрофильных участков с четкими контурами без капсулы, в 18 (19 \%) - локальные или сливные кровоизлияния низкой плотности с четкими неровными контурами. С течением времени гематомы и кровоизлияния рассасывались, поэтому на 6 месяц после операции и позже отсутствует их визуализация, однако наблюдается организация и фиброз.

В 11 (12 \%) пациентов на 6 месяцев наблюдений после операции в местах прицельной электрокоагуляции формируются 2-3 мм гиперэхогенные, неоднородной структуры включения, без четких границ, с неровными и нечеткими контурами. Количество и размер гранулем зависит от гистологической структуры оперируемой ткани, которые при лимфоидной инфильтрации аутоиммунного генеза могут заполнять весь тиреоидный остаток. Дополнительно на этом фоне, первого года исследований, у 18 (19 \%) пациентов можно определить мелкие гиперэхогенные образования, дают звуковую дорожку (кальцинаты). Через 2-3 года после операции установлено сохранения гранулем меньшего размера только у 4 больных. Через 5-6 месяцев после операции у 17 (18 \%) больных в паренхиме изолированно или вокруг гиперэхогенных включений установленны небольшие первичные кисты - гидрофильные участки с четкими контурами. Лишь в 21 (22 \%) обследовании уже с первых дней, при выполнении экономной резекции и операций в зоне перешейка и медиального края обеих долей, случается здоровая (не изменена) паренхима при отсутствии лимфоидной инфильтрации аутоиммунного генеза. В 52 (54 \%) пациентов на 6 месяц после операции структура паренхимы однородная, мелкозернистая без патологических изменений.

Ключевые слова: хирургическое лечение щитовидной железы; высокочастотная электрокоагуляция; тиреоидный остаток. 